\title{
The Influence of Calendar of Health As A Prevention of Stunting In Pre-Marriage Couples
}

\author{
Dhita Kris Prasetyanti*, Meirna Eka Fitriasnani \\ Faculty of Health Sciences, Kadiri University, Indonesia \\ *dhitakris@unik-kediri.ac.id
}

\begin{abstract}
To reduce the incidence of stunting, prevention is needed starting from the pre-conception period, one of the preventive efforts with health education using a health calendar for premarital couples. The purpose of this study was to determine the effect of the health calendar media as an effort to prevent stunting in premarital couples. This study used a pre-experiment. This study used a pre-experimental design with one group pretest and posttest design. The population in this study were pre-marital couples aged $<35$ years and had never been married before as many as 16 premarital couples using the total population sampling technique, statistical test using the Wilcoxon test. The results showed that $81.25 \%$ had less knowledge before being given health education, $87.5 \%$ had good knowledge after being given health education, while $56.27 \%$ had a negative attitude before being given health education and $100 \%$ had a positive attitude after being given health education. . There is an effect of the health calendar media on knowledge and attitudes in premarital couples ( $\mathrm{p}$-value $=0.001$ and 0.003 ). The results showed that there is a need for health education using health calendar media to increase knowledge and attitudes of premarital couples so that it is expected to change behavior to prevent stunting.
\end{abstract}

Keywords: Health Calendar Media, Premarital Couples, Prevention of Stunting 


\section{STRADA Jurnal Ilmiah Kesehatan}

DOI: $10.30994 /$ sjik.v9i2.466

ISSN: 2252-3847 (print); 2614-350X (online)

Vol.9 No.2 November 2020 Page.1300-1308

\section{BACKGROUND}

Indonesia still experiencing nutritional problems and having a serious impact on the development of human resources, one of the nutritional problems that are the main concern is the high incidence of stunting. Stunting is a condition in which toddlers have less length or height compared to age. This condition is measured by a length or height that is more than minus two standard deviations (-2SD) of child growth from WHO. (Perkins et al., 2017). Stunting occurs starting from pre-conception so when a teenager becomes a mother and experiences malnutrition and anemia, it will become worse when pregnant with insufficient nutritional intake, plus when the mother lives in an environment with inadequate sanitation. Adolescent girls in Indonesia aged 15-19 years are at risk of chronic energy deficiency (KEK) by $46.6 \%$ in 2017 . When pregnant, there are $24.2 \%$ of women of fertile age (WUS) 15-49 years with a risk of KEK, and anemia of 37.1\%. (Ministry of Health RI, nd). Based on Nutritional Status Monitoring (PSG) data for the last three years, short children under five have the highest prevalence compared to other nutritional problems such as malnutrition, thinness, and obesity. The prevalence of short children under five has increased from 2016, namely 27.5\% to 29.6\% in 2017 (Ministry of Health RI, 2018) and in 2018 increased to $30.8 \%$, while the prevalence of short children under five in East Java was 32.81\% in 2018 (East Java time, 2019) and the prevalence rate of stunting in children under five in Kediri reached $19.79 \%$, from this data it can be concluded that there is still an incidence of stunting in Kediri district (Cathrina, 2019).

Toddler stunting is a chronic nutritional problem caused by many factors. such as socioeconomic conditions, maternal nutrition during pregnancy, illness in infants, and lack of nutritional intake in infants. Stunting toddlers in the future will have difficulty achieving optimal physical and cognitive development (Kemenkes RI, 2018).

Stunting is caused by multi-dimensional factors and is not only caused by malnutrition factors experienced by pregnant women and children under five, among others, the nutritional status of pregnant women greatly affects the state of health and fetal development. Impaired growth in the womb can cause low birth weight (Utami et al., 2019). The health and nutritional conditions of the mother before and during pregnancy and after delivery affect fetal growth and the risk of stunting. Other factors affecting the mother are the mother's posture (short), the pregnancy is too close, the mother is still a teenager, and the lack of nutritional intake during pregnancy (Kemenkes RI, 2018).

Research in Nepal shows that babies with low birth weight have a higher risk of becoming stunted (Paudel et al., 2012). Birth length of babies is also related to the incidence of stunting, research in Kendal shows that babies with short birth lengths are at high risk of stunting in toddlers (Meilyasari and Isnawati, 2014). Another factor associated with stunting is the intake of exclusive breastfeeding for children under five. Research in Southern Ethiopia has shown that toddlers who are not exclusively breastfed for 6 months have a high risk of stunting (Fikadu et al., 2014). Family socioeconomic status such as family income, parental education, knowledge of mothers about nutrition, and the number of family members can indirectly be related to the incidence of stunting. Toddler feeding behavior, maternal nutritional knowledge have a significant effect on the incidence of stunting. (Nihwan, 2019). However, the most basic of all these factors is insufficient knowledge. Another study stated that 34 respondents found that mothers of stunting children $(61.8 \%)$ had lower knowledge than mothers with normal children $(29.4 \%)$ (Ni' mah and Nadhiroh, 2015).

Efforts to prevent stunting must be done early so that premarital couples, especially women of childbearing age, can prepare for pregnancy well in the first 1000 days of life 


\section{STRADA Jurnal Ilmiah Kesehatan}

DOI: $10.30994 /$ sjik.v9i2.466

ISSN: 2252-3847 (print); 2614-350X (online)

Vol.9 No.2 November 2020 Page.1300-1308

(HPK). To prevent stunting, it is necessary to improve the nutritional status before pregnancy, the knowledge that premarital couples will affect the health of the mother and the fetus in the womb, and also affect the quality of the baby born. However, so far efforts to increase knowledge about stunting have only focused on pregnant women, even though to prepare a quality generation starting before pregnancy, thus the promotional efforts that can be made to prevent stunting are aimed at premarital couples so that they can prepare a stunting-free generation. (Fauziatin et al., 2019).

Efforts to improve stunting can be done by increasing knowledge so that it can increase knowledge and attitudes in improving stunting prevention behavior in children. One of the efforts to increase knowledge, attitudes, and motivation to change behavior is the Information and Education Communication (IEC) method through calendar media. IEC is a way to improve mothers' knowledge, attitudes, and practices to reduce stunting (Medika, 2012), as well as in disseminating information to reach the wider community using printed media in the form of a health calendar shaped like a flipchart or flipchart which has the advantage of being practical. You can adjust the atmosphere yourself and the delivery of messages can be repeated if the communicant (the recipient of the message) does not understand, it can be stored so that it can be read again if needed to generate interest in reading and increase knowledge (L. Marlina and A. Saleh, 2019).

\section{METHODS}

This research is a pre-experimental study with the approach One Group Pre Test Post Test Design in which researchers can test whether there are changes that occur after the treatment. This researcher was done by giving a pre-test before being given treatment, after being given treatment, then giving a post-test. The research was conducted by assessing the level of knowledge and attitudes before being given health education through a health calendar on preventing stunting and a post-test after being given health education through a health calendar. The population in this study were 16 pre-married couples aged $<35$ years and had never been married before using the total population sampling technique. Place of research in Sidorejo Village District of Pare Kediri, a study in AprilSeptember 2020. The variables of this study using an independent variable(Independent), namely knowledge and attitudes. The dependent variable (dependent) the health calendar media to prevent stunting. Respondents were given IEC using a health calendar for preventing stunting for 12 meetings for 3 weeks, and each meeting for 60 minutes. The instrument used was a questionnaire. The analysis in this study using statistical Wilcoxon test.

\section{RESULTS}

1. Specific data

1) Frequency distribution of respondent characteristics based on the knowledge of premarital couples before being given health education through health calendar media to prevent stunting in sidorejo village, pare district, kediri regency in 2020. 


\section{STRADA Jurnal Ilmiah Kesehatan}

DOI: $10.30994 /$ sjik.v9i2.466

ISSN: 2252-3847 (print); 2614-350X (online)

Vol.9 No.2 November 2020 Page.1300-1308

Table 1 Frequency distribution of respondent characteristics based on the knowledge of premarital couples before being given health education through health calendar media to prevent stunting in sidorejo village, pare district, kediri regency in 2020 .

\begin{tabular}{ccc}
\hline Level of Knowledge & Frequency & Percentage \\
\hline Good & 0 & 0 \\
Enough & 3 & 18.75 \\
Less & 13 & 81.25 \\
\hline Total & 16 & 100
\end{tabular}

Based on table 1 it can be interpreted as the majority (81.75\%) respondents who have not been given treatment have less knowledge about stunting prevention efforts.

2) Frequency distribution of respondent characteristics based on knowledge of premarital couples after being given health education through health calendar media in an effort to prevent stunting in Sidorejo Village, Pare District, Kediri Regency in 2020.

Table 2 Frequency distribution of respondent characteristics based on knowledge of premarital couples after being given health education through health calendar media in an effort prevention of stunting in Sidorejo Village, Pare District, Kediri Regency in 2020.

\begin{tabular}{ccc}
\hline Level of Knowledge & Frequency & Percentage \\
\hline Good & 14 & 87.5 \\
Sufficiently & 2 & 12.5 \\
Poor & 0 & 0 \\
\hline Total & 16 & 100
\end{tabular}

Based on table 2 it can be interpreted that most (87.5\%) of respondents have been given treatment has good knowledge about stunting prevention efforts.

3) Frequency distribution of respondent characteristics based on the attitude of pre-married couples before being given health education through the health calendar media in an effort to prevent stunting in Sidorejo Village, Pare District, Kediri Regency in 2020.

Table 3 Frequency distribution of respondent characteristics based on the attitude of premarital couples before being given health education through health calendar media in an effort prevention of stunting in Sidorejo Village, Pare District, Kediri Regency in 2020

\begin{tabular}{ccc}
\hline Attitude & Frequency & Percentage \\
\hline Positive & 7 & 43.75 \\
Negative & 9 & 56.25 \\
\hline Total & 16 & 100 \\
\hline
\end{tabular}


Based on table 3 it can be interpreted that most (56.25\%) respondents who have not been given treatment have negative attitudes about stunting prevention efforts

4) Frequency distribution of respondent characteristics based on the attitude of premarital couples after being given health education through the media health calendar in an effort to prevent stunting in Sidorejo Village, Pare District, Kediri Regency in 2020.

Table 4 The frequency contribution of respondent characteristics based on the attitude of the premarital couple after being given health education through the health calendar media in an effort to prevent stunting in Sidorejo Village, Pare District, Kediri Regency in 2020

\begin{tabular}{lccc}
\hline & Attitude & Frequency & Percentage \\
\hline & Positive & 16 & 100 \\
& Negative & 0 & 0 \\
\hline Total & & 16 & 100 \\
\hline
\end{tabular}

Based on table 4 it can be interpreted as a whole (100\%) respondents who after being given treatment have a positive attitude about efforts to prevent stunting.

5) The effect of knowledge before and after being given health education through the media health calendar in efforts to prevent stunting in Sidorejo Village, Pare District, Kediri Regency in 2020.

Table 5 Frequency Distribution of Respondent Characteristics Based on prior knowledge and after being given health education through the media health calendar in an effort to prevent stunting in Sidorejo Village, Pare District, Kediri Regency in 2020

\begin{tabular}{|c|c|c|c|c|c|c|c|c|}
\hline \multirow{3}{*}{$\begin{array}{l}\text { Effect of } \\
\text { knowledge } \\
\text { of } \\
\text { premarital } \\
\text { couples }\end{array}$} & \multicolumn{6}{|c|}{ Level of Knowledge } & \multirow{2}{*}{\multicolumn{2}{|c|}{ Total }} \\
\hline & \multicolumn{2}{|c|}{ Good } & \multicolumn{2}{|c|}{$\mathrm{Cu}$ Couples } & \multicolumn{2}{|c|}{ Less } & & \\
\hline & $\mathrm{F}$ & $\%$ & $\mathrm{~F}$ & $\%$ & $\mathrm{~F}$ & $\%$ & $\mathrm{~F}$ & $\%$ \\
\hline Before & 0 & 0 & 3 & 18.75 & 13 & 81.25 & 16 & 100 \\
\hline After & 14 & 87.5 & 2 & 12.5 & 0 & 0 & 16 & 100 \\
\hline
\end{tabular}

Based on table 5 above that the level of knowledge before being given health education through the media health calendar can be interpreted, namely that most $(81.25 \%)$ of the respondents have less knowledge and a small portion $(18.75 \%)$ of the respondents have sufficient knowledge. While the level of knowledge after being given health education through the media health calendar can be interpreted, namely that most $(87.5 \%)$ of the respondents have good knowledge and a small proportion $(12.5 \%)$ of respondents have sufficient knowledge. 


\section{STRADA Jurnal Ilmiah Kesehatan}

DOI: $10.30994 /$ sjik.v9i2.466

ISSN: 2252-3847 (print); 2614-350X (online)

Vol.9 No.2 November 2020 Page.1300-1308

Based on the results of statistical tests using thetest, it is Wilcoxon signed rank known that thevalue of $p 0.001$ is smaller than the value of $\alpha=0.05(0.001$ $<0.05)$ so that $\mathrm{H}_{0}$ is rejected and $\mathrm{H}_{1}$ is accepted, meaning that there is an effect of the health calendar media on knowledge about efforts to prevent stunting in premarital couples in Sidorejo Village, Pare District, Kediri Regency in 2020.

6) The influence of attitudes before and after being given health education through health calendar media in efforts to prevent stunting in Sidorejo Village, Pare District, Kediri Regency in 2020.

Table 6 Frequency Distribution of Respondent Characteristics Based on attitude before and after health education is given through the media health calendar in an effort to prevent stunting in Sidorejo Village, Pare District, Kediri Regency in 2020

\begin{tabular}{llllllc}
\hline \multirow{2}{*}{$\begin{array}{c}\text { Effect of } \\
\text { premarital } \\
\text { couple }\end{array}$} & \multicolumn{4}{c}{ attitudes } & \multicolumn{2}{c}{ Total } \\
\cline { 2 - 7 } & $\mathrm{F}$ & $\%$ & $\mathrm{~F}$ & $\%$ & $\mathrm{~F}$ & $\%$ \\
\hline Before & 7 & 43.75 & 9 & 65.25 & 16 & 100 \\
After & 16 & 100 & 0 & 0 & 16 & 100 \\
\hline$p$ value $=0.003$ & $\alpha=0.05$ & & & & \\
\hline
\end{tabular}

Based on table $6 \mathrm{~d}$ i above that the level of attitudes before being given health education through the health calendar media can be interpreted, namely that most $(65.25 \%)$ of the respondents had a negative attitude and almost half $(43.75 \%)$ of the respondents had a positive attitude. While the attitude after being given health education through the media health calendar can be interpreted, namely that all $(100 \%)$ of the respondents have a positive attitude.

Based on the results of statistical tests using thetest, it is Wilcoxon signed rank known that thevalue of $p 0.003$ is smaller than the value of $\alpha=0.05(0.003$ $<0.05)$ so that $\mathrm{H}_{0}$ is rejected and $\mathrm{H}_{1}$ is accepted, meaning that there is an effect of the health calendar media on attitudes about efforts to prevent stunting in premarital couples in Sidorejo Village, Pare Subdistrict, Kediri Regency in 2020.

\section{DISCUSSION}

1) The effect of knowledge before and after being given health education through the media health calendar in an effort to prevent stunting

Based on table 1 it can be interpreted that most $(81.75 \%)$ respondents who have not given treatment have less knowledge about efforts to prevent stunting. Knowledge occurs because of the results of knowing from feeling something through the five senses such as sight, taste, hearing, touch, smell. (Astarani et al., 2020). Knowledge is a form of stimulation of a person obtained through the five senses so that it can lead to attitudes and motivation (WOS Andriani, 2017). Likewise, the formal and informal learning process as well as the experience gained and the ability to remember an object or idea will affect knowledge. One of the factors that can increase the incidence of stunting is due to a lack of knowledge about nutrition and health before and during 


\section{STRADA Jurnal Ilmiah Kesehatan}

DOI: $10.30994 /$ sjik.v9i2.466

ISSN: 2252-3847 (print); 2614-350X (online)

Vol.9 No.2 November 2020 Page.1300-1308

pregnancy (Sari EM, 2016). From the results of the research, most of the premarital couples or prospective brides had never received information about stunting prevention and had no experience of being parents, so most respondents had less knowledge about stunting prevention.

Based on table 2 it can be interpreted that most (87.5\%) respondents who have been given treatment have good knowledge about stunting prevention, while $12.5 \%$ of respondents have sufficient knowledge in preventing stunting. The results of the study showed an increase in knowledge after being given health education, this happened because of the explanation using the flip sheet media of the health calendar in an effort to prevent stunting in premarital couples using language and pictures that were easily understood by premarital couples. In line with the research results, flipchart media is very effective in increasing knowledge and can be an alternative for health education (Fauziatin et al., 2019). A person's ability to remember information that is considered important will increase higher if a person studies the material through the sense of sight or writing because this ability can increase memory by up to $72 \%$ (Medika, 2012). With the health calendar media, after counseling premarital couples can read and repeat what they have learned so that they can increase their knowledge.

Based on the results of statistical tests using thetest, it is Wilcoxon signed rank known that thevalue of $p 0.001$ is smaller than the value of $\alpha=0.05(0.001<0.05)$ so that $\mathrm{H}_{0}$ is rejected and $\mathrm{H}_{1}$ is accepted, meaning that there is an influence of knowledge through the health calendar media about efforts to prevent stunting in premarital couples.

The first 1000 days of life (HPK) starting from conception until the age of the child is 2 years old or also known as the critical period because the highest nutritional needs are in this phase, if not met it can lead to stunting. Stunting is a condition of failure to thrive in children under five years of age (infants under five years) due to chronic lack of energy so that the child is too short. The prevalence of stunting is one of the biggest nutritional problems for children under five in Indonesia. Children are classified as stunting if their length or height is below minus two standard deviations (-2SD) for their age (Ministry of Health, 2018.). Stunting is caused by many factors, one of which is lack of knowledge in fulfilling child nutrition. Lack of nutrients in the first 1000 days of life can affect the development of brain cells and the risk of degenerative diseases increases and is susceptible to infectious diseases (Edwin Danie Olsa et al., 2017).

From the results of the research, after being given treatment, it turns out that there is an effect of knowledge through the media health calendar on efforts to prevent stunting in premarital couples, in line with Andriani's research (2017) that health education can increase knowledge in preventing stunting. Increased knowledge occurs because of the willingness to follow and know the benefits of education. Personal experience and influence from others will influence a person in efforts to prevent stunting. (WOS Andriani, 2017).

2) The influence of pre-marital couples' attitudes before and after being given health education through a health calendar in an effort to prevent stunting.

Based on table 3 it can be interpreted that most (56.25\%) respondents who have not been given treatment have negative attitudes about efforts to prevent stunting. The difference in attitudes that is not too far away is $43.75 \%$ of respondents who have a positive attitude even though they have never received information about 


\section{STRADA Jurnal Ilmiah Kesehatan}

DOI: $10.30994 /$ sjik.v9i2.466

ISSN: 2252-3847 (print); 2614-350X (online)

Vol.9 No.2 November 2020 Page.1300-1308

stunting prevention, indicating that their belief in wanting to change into a better generation to prevent stunting is higher. This is in line with research which states that attitudes will be easier to form if they involve emotional factors (Prayitno, 2018).

Based on table 4 it can be interpreted that all (100\%) respondents after being given treatment have a positive attitude about stunting prevention efforts, in this case the experience of premarital couples in gaining knowledge of stones about stunting prevention is the basis for changing positive attitudes in premarital couples, this is in line with the research. Andriani (2017) states that personal experiences and the presence of outside influences or other people who are considered important will show an increase in attitude. (WOS Andriani, 2017).

Based on the results of statistical tests using thetest, it is Wilcoxon signed rank known that thevalue of $\mathrm{p} 0.003$ is smaller than the value of $\alpha=0.05(0.003<0.05)$ so that $\mathrm{HO}$ is rejected and $\mathrm{H}_{1}$ is accepted, meaning that there is an effect of the health calendar media on attitudes about Efforts to prevent stunting in premarital couples, the results of this study are in line with Kartika's research which shows that there are differences in attitudes before and after being given treatment (Priyoto, 2014). Inthe form of intact attitude, knowledge, thoughts, beliefs and emotions play an important role. According to Priyoto, attitude refers to an individual's evaluation of various aspects of the social world as well as how this evaluation raises an individual's liking or dislike of issues or ideas of other people, social groups and objects. Attitude is the result of considering the advantages and disadvantages of the behavior in question (Priyoto, 2014).

\section{CONCLUSION}

Based on the results of research conducted in Sidorejo Village, Pare District, Kediri Regency, it can be concluded that there is an influence of the health calendar media as an effort to preventmedia stunting in premarital couples. This health calendarwas chosen because it can contain lots of pictures and writing, easy to understand and put in a room that can Reached and read anytime, with the help of the media can increase knowledge and attitudes so that it is expected to change behavior to improve nutritional health status in preventing stunting for premarital couples.

\section{REFERENCES}

Astarani, K., Poernomo, DISH, Idris, DNT, Oktavia, AR, 2020. Prevention of Stunting Through Health Education in Parents of Pre-School Children. Str. J. Ilm. Healthy. 9, 70-77.

Cathrina, R., 2019. The Relationship History of Anemia during Pregnancy with the Incidence of Stunting in Toddlers Aged 24-59 Months in the Work Area of the Pranggang Public Health Center in Punjul Village, Kediri Regency. Poltekkes Kemenkes Malang - Kediri Midwifery Study Program.

Edwin Danie Olsa (last), Sulastri, D., Eliza, Eliza Anas, 2017. The Relationship of Mother's Attitudes and Knowledge of Events in New Children Entering Primary School in Nanggalo District. Andalas Health Journal 6, 523-529.

Fauziatin, N., Kartini, A., Nugraheni, SA, 2019. The Influence of Health Education Using Flip-Sheet Media on Stunting Prevention in Prospective Brides 18, 10.

RI Ministry of Health, 2018. Bulletin jendala health data and information. 2018 1, 1-56. 


\section{STRADA Jurnal Ilmiah Kesehatan}

DOI: $10.30994 /$ sjik.v9i2.466

ISSN: 2252-3847 (print); 2614-350X (online)

Vol.9 No.2 November 2020 Page.1300-1308

Ministry of Health, 2018. Guidelines for behavior change communication strategies to accelerate stunting prevention in Indonesia.

L. Marlina, A. Saleh, 2019. Comparison of the Effectiveness of Print Media (Folders and Posters-Calendar) and Presentation of Zodia Plants on Increasing Public Knowledge. J. Commun. Pembang. 07, 1-20.

Medika, M., 2012. Differences in the Relationship between Working Mothers and Housewives on Development and Development of Children Aged 2-5 Years 12, 7.

Nihwan, N., 2019. Guidance on Counseling of Parents' Understanding in Preventing Stunting in Early Childhood. J. Guide. Extension. Islam 1, 144-156.

Ni'mah, K., Nadhiroh, SR, 2015. Factors Associated with the Incidence of Stunting in Toddlers. Indonesian Nutrition Media. 10, 13-19.

Paudel, R., Pradhan, B., Wagle, RR, Pahari, DP, Onta, SR, 2012. Risk factors for stunting among children: a community based case control study in Nepal. Kathmandu Univ. Med. J. KUMJ 10, 18-24.

Perkins, JM, Kim, R., Krishna, A., McGovern, M., Aguayo, VM, Subramanian, SV, 2017. Understanding the association between stunting and child development in low- and middle-income countries: Next steps for research and intervention. Soc. Sci. Med. 193, 101-109.

Prayitno, 2018. Human Attitudes and Measurements. Yogyakarta: East Java Offset Student Library

. 2019. East Java's Stunting Prevalence Is Higher Than National.East Java Times

2019.Priyoto, 2014. Theory and attitudes in health behavior. Offset Student Library, Yogyakarta.

Sari EM, 2016. The intake of protein, calcium and phosphorus in stunting and non-stunting children aged 24-59 months. J. Nutrition Klin. Indonesia. 12, 152-159.

Utami, RA, Setiawan, A., Fitriyani, P., 2019. Identifying causal risk factors for stunting in children under five years of age in South Jakarta, Indonesia. Enferm. Clínica.

WOS Andriani, 2017. Differences in knowledge, attitudes and motivation of mothers after being given the mother smart grounding ( $\mathrm{msg}$ ) program in preventing stunting in the work area of Puskesmas Puuwatu Kota Kendari in 2017. Jimkesmas 2, 1-9. 